\title{
Anomalous origin of left internal mammary artery arising directly from the aortic arch
}

\author{
Ahmed Hailan, Daniel Obaid, Abbas Zaidi, David Smith
}

Morriston Hospital, Abertawe Bro Morgannwg University Health Board, Swansea, UK

\section{Correspondence to} Dr Abbas Zaidi, abbaszaidi77@gmail.com

Accepted 19 November 2014
CrossMark

To cite: Hailan $A$, Obaid $D$, Zaidi A, et al. BMJ Case Rep Published online: [please include Day Month Year] doi:10.1136/bcr-2014206583

\section{DESCRIPTION}

A 72-year-old man who had undergone coronary artery bypass grafting 18 years previously (including left internal mammary artery (LIMA) graft to the left anterior descending artery) presented with an acute coronary syndrome. He underwent angiography to assess coronary artery bypass graft patency. Attempts to locate the origin of the LIMA in the left subclavian artery were unsuccessful (figure 1A). An aortic arch angiogram was performed using a $4 \mathrm{Fr}$ Pigtail catheter (figure 1B). This revealed that the LIMA arose directly from the aortic arch, which was subsequently selectively engaged with a $5 \mathrm{Fr}$ multipurpose catheter (figure 1C).

The LIMA arises from the inferior aspect of the proximal third of the subclavian artery in $92 \%$ of cases, the middle third in $7 \%$ and the distal third in $1 \%$ of cases. There are reports of the LIMA originating from the junction of the left subclavian artery and aorta, ${ }^{1}$ and from the vertebral artery. ${ }^{2}$ To the best of our knowledge, this is the first description of the LIMA arising directly from the aortic arch. Angiographic evaluation of the LIMA is not routinely performed prior to coronary artery bypass grafting. This case therefore exemplifies the importance of performing non-selective aortic arch angiography before concluding that the LIMA graft is occluded.

\section{Learning points}

In a minority of cases (8\%), the left internal mammary artery may not arise from the inferior aspect of the proximal third of the subclavian artery.

- Non-selective aortic arch angiography should always be performed prior to concluding that a left internal mammary artery graft is occluded.

Competing interests None.

Patient consent Obtained.

Provenance and peer review Not commissioned; externally peer reviewed.

\section{REFERENCES}

1 Chavez J, Osborn LA. Anomalous origin of LIMA from the lateral junction of the left subclavian artery and aorta. Catheterization Cardiovas Diag 1996:37:168-9.

2 Kirsch J, Williamson EE. Aberrant left internal mammary artery off an aberrant vertebral artery. Eur Heart J 2008;29:1782.

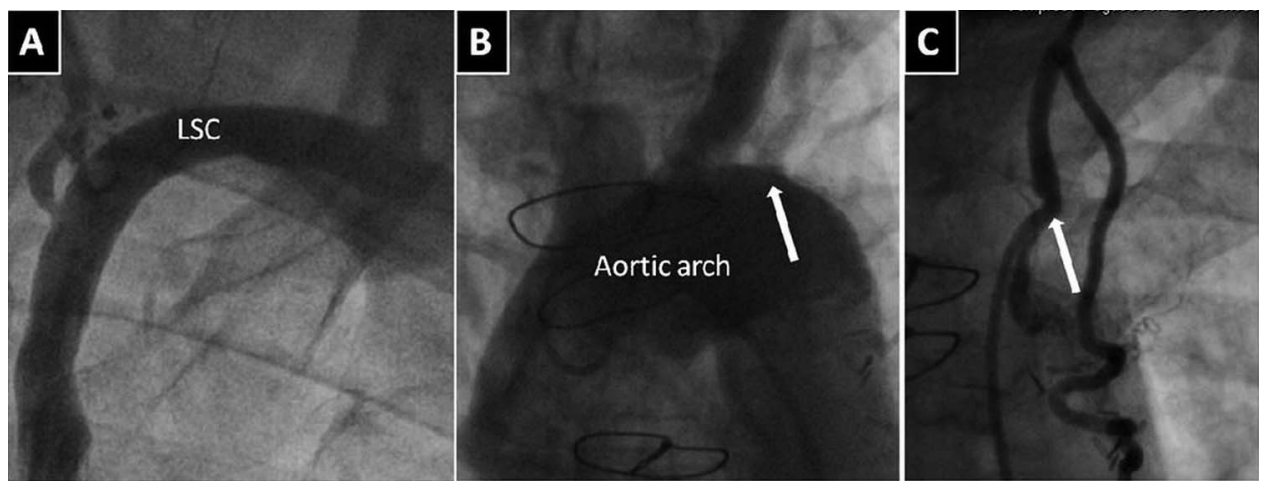

Figure 1 (A) No left internal mammary artery (LIMA) seen arising from the left subclavian (LSC) artery. (B) Origin of LIMA seen from aortic arch (white arrow). (C) Selective intubation of LIMA. 
Copyright 2014 BMJ Publishing Group. All rights reserved. For permission to reuse any of this content visit http://group.bmj.com/group/rights-licensing/permissions.

BMJ Case Report Fellows may re-use this article for personal use and teaching without any further permission.

Become a Fellow of BMJ Case Reports today and you can:

- Submit as many cases as you like

- Enjoy fast sympathetic peer review and rapid publication of accepted articles

- Access all the published articles

- Re-use any of the published material for personal use and teaching without further permission

For information on Institutional Fellowships contact consortiasales@bmjgroup.com

Visit casereports.bmj.com for more articles like this and to become a Fellow 